University of Wollongong

Research Online

Faculty of Engineering and Information

Faculty of Engineering and Information

Sciences - Papers: Part A

Sciences

$1-1-2010$

\title{
Mechanical property development during UOE forming of large diameter pipeline steels
}

Andrii Kostryzhev

University of Birmingham, andrii@uow.edu.au

Martin Strangwood

University of Birmingham

Claire L. Davis

University of Birmingham

Follow this and additional works at: https://ro.uow.edu.au/eispapers

Part of the Engineering Commons, and the Science and Technology Studies Commons

Research Online is the open access institutional repository for the University of Wollongong. For further information contact the UOW Library: research-pubs@uow.edu.au 


\title{
Mechanical property development during UOE forming of large diameter pipeline steels
}

\author{
Abstract \\ Mechanical properties of large diameter welded steel pipes depend on the thermomechanically controlled \\ rolled (TMCR) plate microstructure and UOE pipe-forming cold deformation sequence. Strength from \\ plate to pipe may increase (work-hardening) or decrease (the Bauschinger effect). Bauschinger effect \\ parameters depend on steel composition and plate processing history. The present study is examining \\ two pipeline grades: X60 ( $\mathrm{Nb}$-alloyed) and X65 ( $\mathrm{Nb}$ - and V-alloyed). Mechanical properties are determined \\ by grain refinement, solid solution, precipitation strengthening mechanisms, and work-hardening (work- \\ softening). The reverse deformation yield drop increases with an increase in the precipitate particle \\ volume fraction and pre-strain. Annealing, leading to a decrease in the dislocation density, reduces the \\ yield drop. The Bauschinger parameters are being quantitatively related to the particle type, size, and \\ volume fraction, and the dislocation density.
}

\section{Keywords}

uoe, development, diameter, large, property, mechanical, steels, forming, pipeline, during

Disciplines

Engineering | Science and Technology Studies

\section{Publication Details}

Kostryzhev, A. G., Strangwood, M. \& Davis, C. L. (2010). Mechanical property development during UOE forming of large diameter pipeline steels. Materials and Manufacturing Processes, 25 (1-3), 41-47. 


\title{
MECHANICAL PROPERTY DEVELOPMENT DURING UOE FORMING OF LARGE DIAMETER LINE-PIPE STEELS
}

\author{
A. G. Kostryzhev, M. Strangwood, and C. L. Davis \\ Department of Metallurgy and Materials, University of Birmingham, \\ Edgbaston, Birmingham, B15 2TT \\ E-mail: C.L.Davis@bham.ac.uk
}

\begin{abstract}
Mechanical properties of large diameter welded steel pipes depend on the TMCR-plate microstructure and UOE pipe-forming cold deformation sequence. Strength from plate to pipe may increase (work-hardening) or decrease (the Bauschinger effect). Bauschinger effect parameters depend on steel composition and plate processing history.The present study is examining two line-pipe grades: X60 (Nb-alloyed) and X65 ( $\mathrm{Nb}$ - and Valloyed). Mechanical properties are determined by grain refinement, solid solution, precipitation strengthening mechanisms and work-hardening (work-softening). The reverse deformation yield drop increases with the precipitate particle volume fraction and pre-strain increase. Annealing, leading to the dislocation density decrease, decreases the yield drop. The Bauschinger parameters are being quantitatively related to the particle volume fraction and dislocation density.
\end{abstract}

\section{INTRODUCTION}

Mechanical properties of large diameter (> $400 \mathrm{~mm}$ ) welded steel pipes for the oil and gas industry depend on the thermomechanically controlled rolled (TMCR) plate microstructure and the UOE forming process deformation sequence (Figure 1). The TMCR plate microstructure influences the properties via grain refinement, solid solution and precipitation strengthening mechanisms, and retained workhardening (dislocation substructure). The relative contribution of the strengthening mechanisms depends on the steel composition and rolling process parameters. Cold deformation influences on mechanical properties, i.e. strength increase due to work-hardening or decrease due to the Bauschinger effect, are known to be dependent on the strain level, strain direction and the steel chemistry. Severe application conditions (low temperature, high internal pressure, corrosive environment) require high strength with simultaneously high toughness for the line-pipe material. Together with the need for good weldability, this has led to decreasing carbon content and increasing microalloying element level in the steel chemistry (Table 1, [1-5]). The combined action of microalloying, TMCR processing and accelerated cooling results in significant grain refinement and precipitation strengthening $[6,7,8]$.

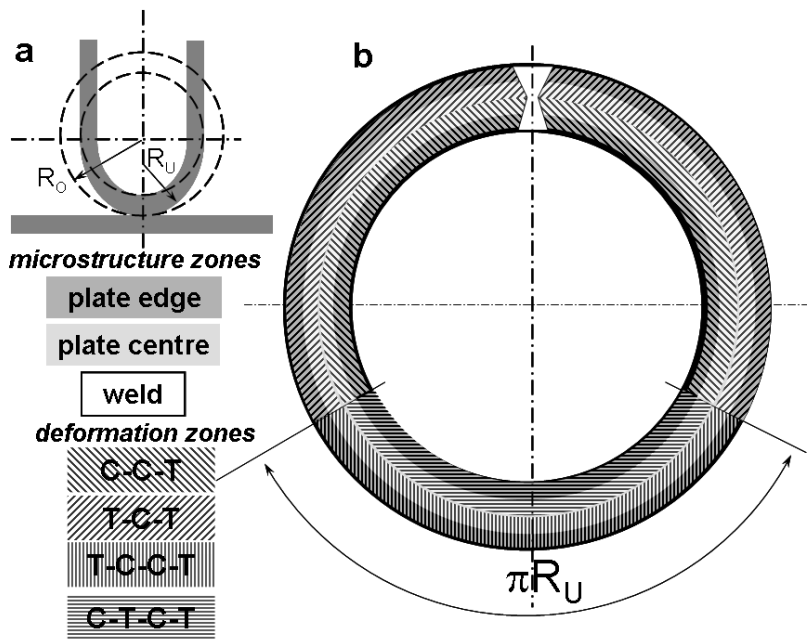

Figure 1 (a) Schematic diagram of the UOE forming process: $R_{U}$ and $R_{O}$ - outer radius of a pipe after $U$ ing and O-ing stages of forming; (b) Property zones in a pipe cross section after the UOE forming: $\mathrm{C}$ - compression, $\mathrm{T}-$ tension

The influence of the Bauschinger effect on pipe properties was observed in two ways: pipe testing (flattened specimens showed 20\% lower yield strength than pipe rings $[1,9])$, and plate to pipe property change (the yield stress decrease from plate to pipe depending on 
strain level [10]). Recent investigations showed a dependence of the Bauschinger effect on the steel chemical composition and plate processing history [11,12]. Using the back stress [13] and Orowan [14] theories, a Bauschinger stress parameter dependence on microalloy particle volume fraction has been found
[15]. In this article, the influence of particle type, size, volume fraction and number density and dislocation density on the strength of pipeline steels, and the Bauschinger effect in particular, is presented.

Table 1 Typical composition and mechanical properties of line-pipe steel plates

\begin{tabular}{|c|c|c|c|c|c|c|}
\hline \multirow{2}{*}{$\begin{array}{l}\text { Steel } \\
\text { grade }\end{array}$} & \multirow{2}{*}{ Typical composition, wt $\%$} & \multirow{2}{*}{ Process } & \multicolumn{3}{|c|}{ Mechanical properties } & \multirow{2}{*}{ Ref } \\
\hline & & & Yield,MPa & UTS,MPa & $\mathrm{CVN}^{*}, \mathrm{~J}$ & \\
\hline X60 & $0.12 \mathrm{C}-0.33 \mathrm{Si}-1.35 \mathrm{Mn}-0.04 \mathrm{Nb}-0.06 \mathrm{~V}$ & TMCR & 485 & 565 & & [1] \\
\hline X65 & $\begin{array}{l}0.08 \mathrm{C}-0.3 \mathrm{Si}-1.6 \mathrm{Mn}-0.08 \mathrm{Nb}-0.08 \mathrm{~V}- \\
0.017 \mathrm{Ti}-0.27 \mathrm{Ni}\end{array}$ & TMCR & $485-500$ & $570-600$ & $\begin{array}{c}260 \\
\left(-30^{\circ} \mathrm{C}\right)\end{array}$ & {$[2,3]$} \\
\hline $\mathrm{X} 70$ & $\begin{array}{l}0.09 \mathrm{C}-0.25 \mathrm{Si}-1.69 \mathrm{Mn}-0.05 \mathrm{Nb}- \\
0.08 \mathrm{~V}-0.003 \mathrm{Ti}-0.22 \mathrm{Ni}-0.01 \mathrm{Mo}\end{array}$ & TMCR & $500-580$ & $600-790$ & $\begin{array}{c}200 \\
\left(-10^{0} \mathrm{C}\right)\end{array}$ & [3] \\
\hline $\mathrm{X} 80$ & $\begin{array}{l}0.08 \mathrm{C}-0.4 \mathrm{Si}-1.9 \mathrm{Mn}-0.044 \mathrm{Nb}- \\
0.019 \mathrm{Ti}-0.2 \mathrm{Ni}-0.01 \mathrm{Mo}-0.03 \mathrm{Cr}\end{array}$ & $\begin{array}{l}\text { TMCR + } \\
\text { acc.cooling }\end{array}$ & 600 & 730 & $\begin{array}{c}180 \\
\left(-20^{\circ} \mathrm{C}\right)\end{array}$ & [3] \\
\hline X100 & $\begin{array}{c}0.06 \mathrm{C}-0.33 \mathrm{Si}-1.95 \mathrm{Mn}-0.048 \mathrm{Nb}- \\
0.019 \mathrm{Ti}-0.24 \mathrm{Ni}-0.3 \mathrm{Mo}\end{array}$ & $\begin{array}{l}\text { TMCR + } \\
\text { acc.cooling }\end{array}$ & $740-760$ & $780-820$ & $\begin{array}{c}270 \\
\left(-10^{\circ} \mathrm{C}\right)\end{array}$ & [4] \\
\hline X120 & $\begin{array}{c}0.05 \mathrm{C}-0.30 \mathrm{Si}-1.80 \mathrm{Mn}-0.80 \mathrm{Cr}- \\
0.042 \mathrm{Nb}-0.017 \mathrm{Ti}-2.1 \mathrm{Ni}-0.70 \mathrm{Mo}\end{array}$ & $\begin{array}{c}\text { TMCR + } \\
\text { acc.cooling }\end{array}$ & $840-860$ & $940-1130$ & $\begin{array}{c}260 \\
\left(-30^{\circ} \mathrm{C}\right)\end{array}$ & {$[4,5]$} \\
\hline
\end{tabular}

* CVN - Charpy V-notch energy

\section{MATERIALS TECHNIQUES}

AND

Two different steel plates were provided by Corus plc, Plates and Commercial Steels (Table 2). The C-Nb plates were $10.2 \mathrm{~mm}$ in thickness and $\mathrm{C}-\mathrm{Nb}-\mathrm{V} 10.5$ $\mathrm{mm}$. Mechanical properties meet the requirements of API for the grade X60 (C-Nb) and X65 (C-Nb-V) (Table 1). The microstructure and mechanical property investigation was carried out for both steels in as-rolled and annealed conditions. Annealing at $550^{\circ} \mathrm{C}$ for $30 \mathrm{~min}$ was applied to modify the dislocation structure and microalloy particle distributions, without affecting the grain size and the second phase (pearlite) content.

Table 2 Plate composition in weight $\%$

\begin{tabular}{|l|c|c|c|c|c|c|c|}
\hline $\begin{array}{c}\text { Steel } \\
\text { grade }\end{array}$ & $\mathbf{C}$ & $\mathbf{S i}$ & $\mathbf{M n}$ & $\mathbf{P}$ & $\mathbf{S}$ & $\mathbf{C r}$ & $\mathbf{A l}$ \\
\hline $\mathrm{C}-\mathrm{Nb}$ & 0.10 & 0.37 & 1.36 & 0.012 & 0.006 & 0.017 & - \\
\hline $\mathrm{C}-\mathrm{Nb}-\mathrm{V}$ & 0.07 & 0.34 & 1.47 & 0.012 & 0.003 & 0.013 & - \\
\hline & $\mathbf{N i}$ & $\mathbf{C u}$ & $\mathbf{N b}$ & $\mathbf{V}$ & $\mathbf{N}$ & $\mathbf{T i}$ & $\mathbf{M o}$ \\
\hline $\mathrm{C}-\mathrm{Nb}$ & 0.016 & 0.009 & 0.034 & 0.001 & 0.002 & 0.001 & 0.002 \\
\hline $\mathrm{C}-\mathrm{Nb}-\mathrm{V}$ & 0.021 & 0.015 & 0.046 & 0.061 & 0.004 & 0.002 & 0.002 \\
\hline
\end{tabular}

For optical microscopy and image analysis sections of approximately $10 \mathrm{~mm}$ x $10 \mathrm{~mm}$ x $10 \mathrm{~mm}$ in size were cut from the as-received plates, mounted in conductive bakelite parallel and perpendicular to the rolling direction, ground and polished to a $1 \mu \mathrm{m}$ finish then etched in $2 \%$ nital. The specimens were imaged using Leica DMRX and Zeiss Axioskop2 microscopes and analysed using KS 300 and KS 400 software. Grain size was measured as average grain diameter for 800-2000 grains and pearlite percent for 5 images at a magnification of $100 x\left(0.161 \mathrm{~mm}^{2}\right)$ or at a magnification of $200 \mathrm{x}\left(0.039 \mathrm{~mm}^{2}\right)$ depending on the steel grade. Measurements were made across the plate thickness in $0.4 \mathrm{~mm}$ steps.

Scanning electron microscopy (SEM) was carried out using a Jeol JSM-7000F field emission gun scanning electron microscope. $\mathrm{Nb}$ - and $\mathrm{Nb}$-Ti-rich precipitates were imaged from 4 regions, ferrite and pearlite, sub-surface and mid-thickness, and characterised in terms of size, morphology and area fraction. For the determination of the particle size distributions and area fraction in the $\mathrm{C}-\mathrm{Nb}$ steel 630 particles from $15585 \mu^{2}$ and in the C-Nb-V steel 1064 
particles from $10780 \mu \mathrm{m}^{2}$ total area were imaged.

Transmission electron microscopy (TEM) was carried out on Philips-CM20 and Philips Tecnai F20 field emission gun TEMs. $\mathrm{V}$ - and $\mathrm{Cu}$-rich particles in the $\mathrm{C}-\mathrm{Nb}-\mathrm{V}$ steel were imaged from 2 regions, plate mid-thickness and sub-surface. For the determination of the particle size distributions and volume fraction 469 particles from $3.91 \mu^{2}$ at sub-surface position and 918 particles from $3.12 \mu \mathrm{m}^{2}$ at mid-thickness position in $\mathrm{C}-\mathrm{Nb}-\mathrm{V}$ as-rolled steel, and 152 particles from $0.81 \mu^{2}$ at sub-surface position and 688 particles from $3.35 \mu \mathrm{m}^{2}$ at mid-thickness position in the $\mathrm{C}-\mathrm{Nb}-\mathrm{V}$ annealed steel were imaged. Foil thickness was determined using a convergent beam diffraction technique [16]. Precipitate compositions were determined using energy dispersive $X$-ray spectroscopy (EDS) point analysis in the Jeol-6300 SEM (Noran EDS, Vantage software), Jeol-7000F SEM (Inca Oxford EDS), Philips-CM20 TEM (Link Oxford EDS) and Philips Tecnai F20 TEM ( Link ISIS Oxford EDS). For the Ti-, Nb-, V- and $\mathrm{Cu}$-rich precipitate chemical composition investigation 54 particles in the $\mathrm{C}-\mathrm{Nb}$ and 95 particles in the $\mathrm{C}-\mathrm{Nb}-\mathrm{V}$ steel were used. Dislocation sub-structures were studied using Philips-CM20 and Philips Tecnai F20 TEMs. For the dislocation density determination 20 representative regions were imaged in each of the asrolled and annealed $\mathrm{C}-\mathrm{Nb}$ and $\mathrm{C}-\mathrm{Nb}-\mathrm{V}$ steels from the plate mid-thickness position. The mid-thickness position was selected to correlate dislocation density with mechanical property data obtained from the compression-tension samples.

Compression-tension testing was carried out on an ESH $250 \mathrm{kN}$ servo-hydraulic twin column low speed ramp universal testing machine. For the stress-strain curve determination 4 cylindrical specimens of 4.5 $\mathrm{mm}$ diameter and $13 \mathrm{~mm}$ gauge length were cut in the transverse orientation to the rolling direction from the $\mathrm{C}-\mathrm{Nb}$ and $\mathrm{C}-\mathrm{Nb}-\mathrm{V}$ as-received and annealed steel plates. Thermodynamic modelling was carried out using version $\mathrm{Q}$ of Thermo-Calc using the bulk alloy composition as an input. Equilibrium phase balances within the temperature range 600-1600 $\mathrm{K}$ were calculated along with phase compositions. For ferrite micro-hardness distributions across the plate thickness 5 indents for each point were measured using a Shimadzu Vickers micro-hardness tester at intervals of $0.2 \mathrm{~mm} .500 \mathrm{~g}$ load was used.

\section{RESULTS AND DISCUSSION}

\section{Microstructure characterisation}

Optical microscopy of the two steels showed banded ferrite-pearlite microstructures. Sub-surface plate areas showed smaller ferrite grain sizes than the mid-thickness. Second phase (pearlite) content increased towards the centreline consistent with macrosegregation. Average pearlite content decreased with decreasing carbon content. Average microhardness increased slightly in the $\mathrm{C}-\mathrm{Nb}-\mathrm{V}$ steel compared to the $\mathrm{C}-\mathrm{Nb}$ steel due to grain refinement, precipitation strengthening and work-hardening from a lower finish rolling temperature (Table 3).

Table 3 Microstructure characterisation

\begin{tabular}{|c|c|c|c|c|c|c|}
\hline \multirow{2}{*}{$\begin{array}{c}\text { Steel } \\
\text { grade }\end{array}$} & \multicolumn{2}{|c|}{$\begin{array}{c}\text { Grain size, } \\
\mu \mathrm{m}\end{array}$} & \multicolumn{3}{|c|}{ Pearlite content, \% } & \multirow{2}{*}{ HV } \\
\cline { 2 - 6 } & surface & centre & surface & centre & T-Calc & \\
\hline $\mathrm{C}-\mathrm{Nb}$ & $\begin{array}{c}2.1 \\
\pm 0.2\end{array}$ & $\begin{array}{c}3.0 \\
\pm 0.1\end{array}$ & $\begin{array}{c}7.0 \\
\pm 0.6\end{array}$ & $\begin{array}{c}11.6 \\
\pm 1.1\end{array}$ & 12.1 & $\begin{array}{c}188 \\
\pm 16\end{array}$ \\
\hline $\mathrm{C}-\mathrm{Nb}-\mathrm{V}$ & $\begin{array}{c}1.9 \\
\pm 0.2\end{array}$ & $\begin{array}{c}2.9 \\
\pm 0.1\end{array}$ & $\begin{array}{c}3.1 \\
\pm 0.7\end{array}$ & $\begin{array}{c}6.1 \\
\pm 0.8\end{array}$ & 6.5 & $\begin{array}{c}194 \\
\pm 14\end{array}$ \\
\hline
\end{tabular}

\section{SEM and TEM study of precipitates}

SEM EDS of the precipitated particles in both steels revealed these to be $\mathrm{Nb}$-rich and $\mathrm{Nb}$-Ti-rich, which corresponds to Thermo-Calc predictions (Figure 2). As it was impossible to separate $\mathrm{Nb}$ and $\mathrm{Nb}-\mathrm{Ti}$ particle distributions, their average diameter and area fraction were calculated together. For the number of particles measured in this work area fraction can be considered equal to the volume fraction and compared with the Thermo-Calc theoretical prediction. Analysis of the 
obtained results, Table 4, shows the volume fraction in pearlite to be larger than that in ferrite due to microsegregation, which is consistent with previous research [17]. As a ferrite band is approximately two times broader than a pearlite band, the average plate sub-surface and mid-thickness values of precipitate characteristics were calculated as follows:

Average $=(1 \mathrm{x}$ In-pearlite $+2 \mathrm{x}$ In-ferrite $) / 3$.

Average particle diameter and volume fraction in the $\mathrm{C}-\mathrm{Nb}$ steel increase towards the mid-thickness of the plates due to macrosegregation and slower cooling rates during solidification. However, in the $\mathrm{C}-\mathrm{Nb}-\mathrm{V}$ steel no significant difference in average particle diameter and volume fraction was observed between the sub-surface and mid-thickness. Particle volume fraction increases with the increase in microalloying as was predicted by Thermo-Calc. The smaller Nb-rich particle diameter observed in the $\mathrm{C}-\mathrm{Nb}-\mathrm{V}$ steel can be explained by the processing variable differences, namely lower finish roll temperature for the $\mathrm{C}-\mathrm{Nb}-\mathrm{V}$ steel $\left(735{ }^{\circ} \mathrm{C}\right)$ than for the $\mathrm{C}-\mathrm{Nb}$ steel $\left(745{ }^{\circ} \mathrm{C}\right)$, and greater number of $\mathrm{V}$-rich particles. The measured value for the particle volume fraction in the $\mathrm{C}-\mathrm{Nb}-\mathrm{V}$ steel is significantly lower than predicted by Thermo-Calc, as SEM measurements do not take into account many fine precipitates. Particle number density corresponds to the distribution of the volume fraction.
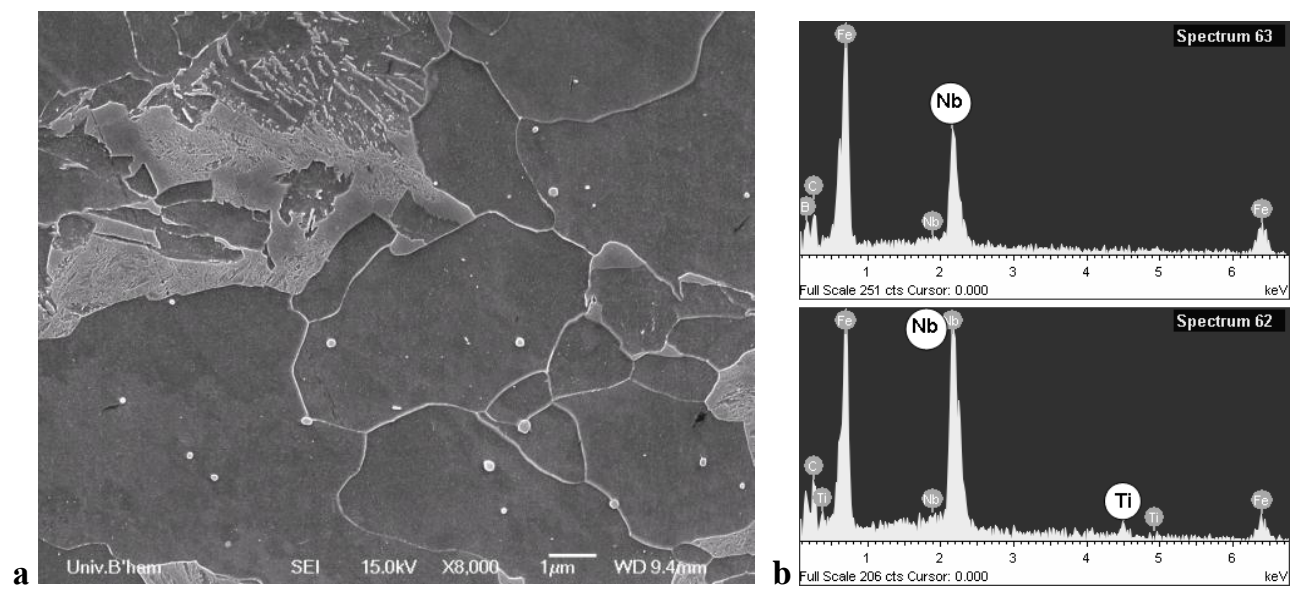

Figure 2 Typical (a) SEM image from the $\mathrm{C}-\mathrm{Nb}-\mathrm{V}$ steel mid-thickness pearlite region and (b) EDS spectra of microalloy particles

Table 4 Measurement results for the Nb-rich particles

\begin{tabular}{|c|c|c|c|c|c|c|c|c|c|c|c|c|c|}
\hline \multirow{3}{*}{\multicolumn{2}{|c|}{$\begin{array}{c}\text { area of } \\
\text { precipitation }\end{array}$}} & \multicolumn{4}{|c|}{$\begin{array}{c}\text { average } \\
\text { diameter, } \mathrm{nm}\end{array}$} & \multicolumn{4}{|c|}{ volume fraction } & \multicolumn{4}{|c|}{ number density, $\mu \mathrm{m}^{-3}$} \\
\hline & & \multirow{2}{*}{\multicolumn{2}{|c|}{$\mathrm{C}-\mathrm{Nb}$}} & \multirow{2}{*}{\multicolumn{2}{|c|}{$\mathrm{C}-\mathrm{Nb}-\mathrm{V}$}} & \multirow{2}{*}{\multicolumn{2}{|c|}{\begin{tabular}{l|}
$\mathbf{C}-\mathbf{N b}$ \\
$=0.000365$
\end{tabular}}} & \multirow{2}{*}{\multicolumn{2}{|c|}{$\begin{array}{c}\text { C-Nb-V } \\
\mathrm{TC}^{*}=0.001445\end{array}$}} & \multirow{2}{*}{\multicolumn{2}{|c|}{$\mathrm{C}-\mathrm{Nb}$}} & \multirow{2}{*}{\multicolumn{2}{|c|}{ C-Nb-V }} \\
\hline & & & & & & & & & & & & & \\
\hline \multirow{2}{*}{$\begin{array}{c}\text { sub- } \\
\text { surface }\end{array}$} & ferrite & 88 & \multirow{2}{*}{89} & 67 & \multirow{2}{*}{68} & $4.4 \cdot 10^{-5}$ & \multirow{2}{*}{$6 \cdot 10^{-5}$} & 0.000372 & \multirow{2}{*}{$-4.07 \cdot 10^{-4}$} & 0.12 & \multirow{2}{*}{0.16} & 2.36 & \multirow{2}{*}{2.47} \\
\hline & pearlite & 90 & & 71 & & $9.7 \cdot 10^{-5}$ & & 0.000476 & & 0.25 & & 2.54 & \\
\hline \multirow{2}{*}{$\begin{array}{c}\text { mid- } \\
\text { thickness }\end{array}$} & ferrite & 132 & \multirow{2}{*}{131} & 58 & \multirow{2}{*}{8} & $6.7 \cdot 10^{-5}$ & \multirow{2}{*}{$5 \cdot 10^{-4}$} & 0.000165 & \multirow{2}{*}{$4.22 \cdot 10^{-4}$} & 0.06 & \multirow{2}{*}{0.42} & 1.61 & \multirow{2}{*}{2.56} \\
\hline & pearlite & 128 & & 88 & & 0.001325 & & 0.000937 & & 1.21 & & 2.63 & \\
\hline
\end{tabular}

$* \mathrm{f}_{\mathrm{TC}}$ - particle volume fraction calculated with Thermo-Calc

TEM investigation was carried out for both $\mathrm{C}-\mathrm{Nb}$ and $\mathrm{C}-\mathrm{Nb}-\mathrm{V}$ steels in as-rolled and annealed conditions. Annealing at $550{ }^{0} \mathrm{C}$ for $30 \mathrm{~min}$ with further air cooling was carried out to modify the dislocation structure and particle distributions in order to investigate their influence on the Bauschinger effect. However, this heat-treatment schedule did not influence the particle distributions in the $\mathrm{C}-\mathrm{Nb}$ steel, which corresponds with the reported stability in ferrite [18] and Thermo-Calc predicted stability of $\mathrm{NbC}$ and $\mathrm{Nb}(\mathrm{C}, \mathrm{N})$ below $680{ }^{\circ} \mathrm{C}$. In the $\mathrm{C}-\mathrm{Nb}-\mathrm{V}$ steel particle growth and precipitation of new small particles was 
observed as a result of annealing. TEM EDS study of the particles smaller than $50 \mathrm{~nm}$ in the $\mathrm{C}-\mathrm{Nb}-\mathrm{V}$ steel revealed these to be $\mathrm{Nb}-, \mathrm{V}$ - and $\mathrm{Cu}$-rich (Figure 3). As it was difficult to separate $\mathrm{V}$-rich and $\mathrm{CuS}$ particle distributions their parameters were calculated together (Table 5). In the as-rolled steel particle diameter decrease and number density increase towards midthickness can be explained by the following reasons: dislocation density increase from sub-surface towards mid-thickness leads to an increased number of nucleation sites and $\mathrm{Cu}$-rich particles, precipitating at

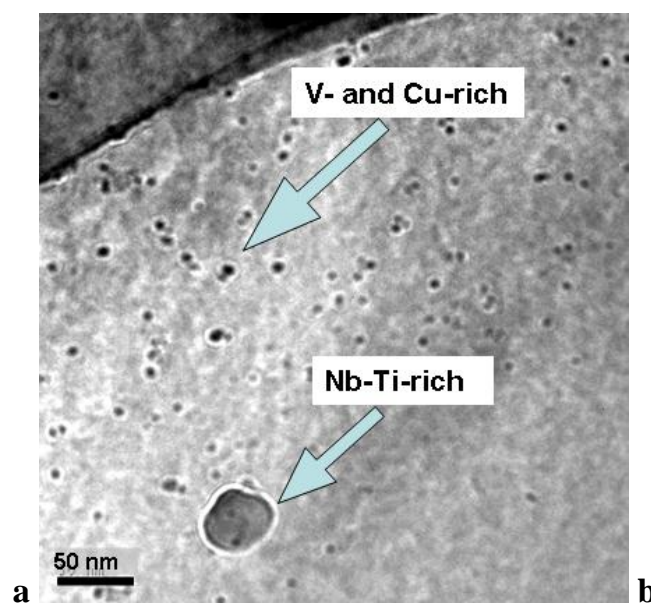

lower temperatures than $\mathrm{Nb}-\mathrm{V}$-rich particles, have less time for growth. In the annealed steel $\mathrm{Cu}$-rich particle diameter increase and number density decrease at the mid-thickness position can be explained by the simultaneous growth of large and dissolution of small particles. Particle number density increase at the sub-surface position after annealing is related to precipitation of new $\mathrm{Cu}$-rich particles, which corresponds to reported precipitation at 450$500{ }^{0} \mathrm{C}$ depending on time $[19,20]$.
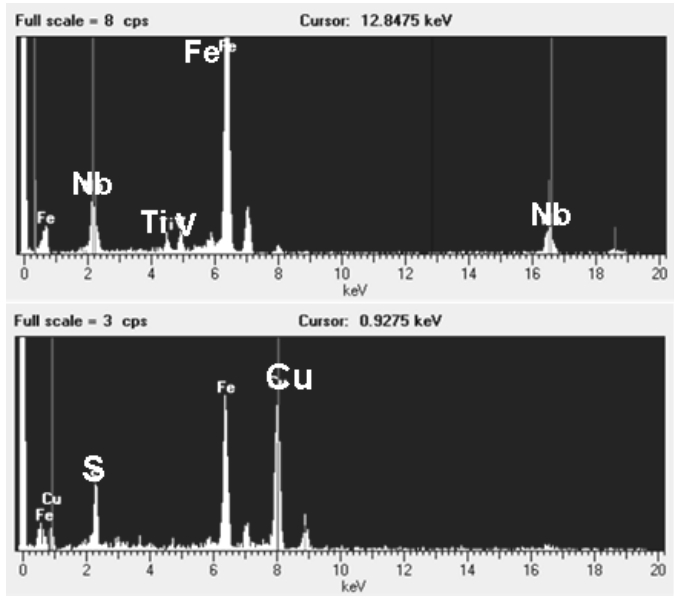

Figure 3 Typical (a) TEM image from the C-Nb-V steel and (b) EDS spectra of the microalloy particles

Table 5 Measurement results for microalloy particles smaller than $50 \mathrm{~nm}$ in the $\mathrm{C}-\mathrm{Nb}-\mathrm{V}$ steel

\begin{tabular}{|l|c|c|c|c|}
\hline \multirow{2}{*}{ Parameter } & \multicolumn{2}{c|}{ As-rolled } & \multicolumn{2}{c|}{ Annealed } \\
\cline { 2 - 5 } & sub-surface & mid-thickness & sub-surface & mid-thickness \\
\hline predominant chemistry & $\mathrm{Nb}-\mathrm{V}$ & $\mathrm{Cu}$ & $\mathrm{Nb}-\mathrm{V}-\mathrm{Cu}$ & $\mathrm{Cu}$ \\
\hline average diameter, $\mathrm{nm}$ & 7.9 & 6.3 & 8.0 & 16.3 \\
\hline volume fraction & 0.00069 & 0.00118 & 0.00096 & 0.00384 \\
\hline number density, $\mu \mathrm{m}^{-3}$ & 1578 & 3873 & 2469 & 1426 \\
\hline
\end{tabular}

\section{Dislocation sub-structure}

Thin foil TEM imaging of both steels in the as-rolled and annealed conditions revealed dislocation substructures with uniform dislocation density (Figure 4,a). Clusters and cell arrangements were also observed in some grains (Figure 4,b). Dislocation loops were numerously present in the $\mathrm{C}-\mathrm{Nb}-\mathrm{V}$ steel, though in the $\mathrm{C}-\mathrm{Nb}$ steel they were scarce. Due to the lower finish rolling temperature, the dislocation density in the $\mathrm{C}-\mathrm{Nb}-\mathrm{V}$ steel is higher than in the $\mathrm{C}-\mathrm{Nb}$ steel (Table 6). Annealing leads to a dislocation density decrease due to annihilation. Absolute values of the dislocation density are in good agreement with the reported data for hot-rolled low carbon steels [21,22] and TMCR-processed X80 steel [3].

Table 6 Dislocation density at plate mid-thickness position, $\times 10^{14} \mathrm{~m}^{-2}$

\begin{tabular}{|c|c|c|c|c|c|c|}
\hline \multirow{2}{*}{ condition } & \multicolumn{3}{|c|}{ C-Nb } & \multicolumn{3}{c|}{ C-Nb-V } \\
\cline { 2 - 7 } & $\min$ & $\max$ & average & $\min$ & $\max$ & average \\
\hline as-rolled & 1.9 & 3.1 & 2.3 & 2.9 & 5.2 & 4.0 \\
\hline annealed & 0.8 & 2.0 & 1.1 & 1.0 & 2.8 & 1.5 \\
\hline
\end{tabular}



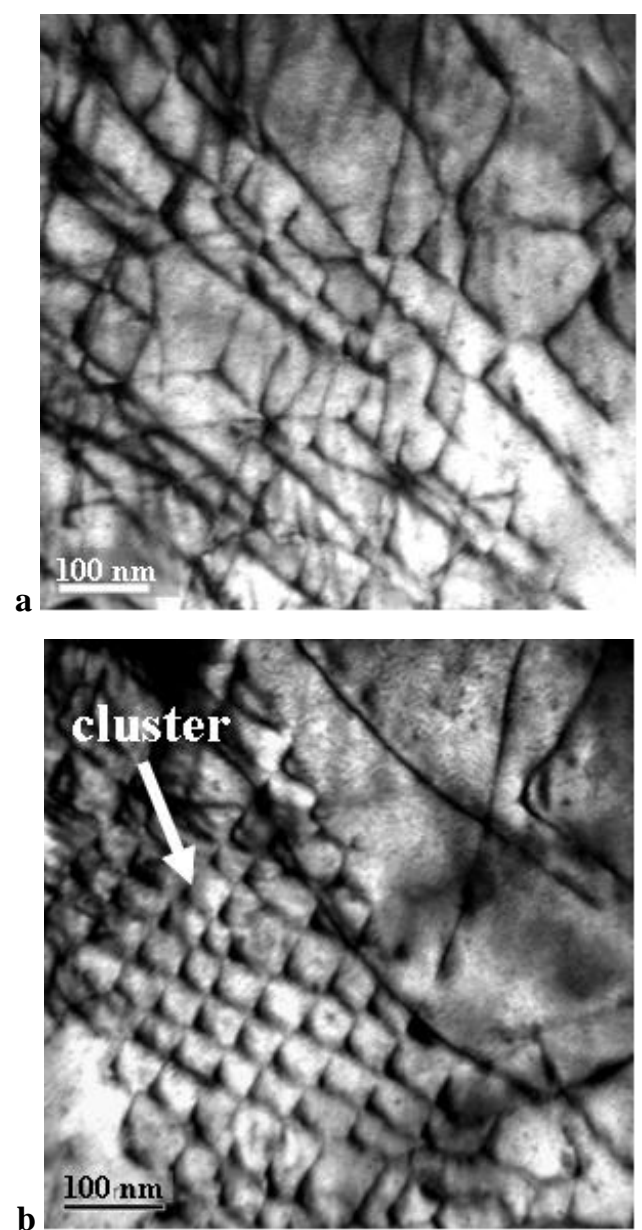

Figure 4 Typical TEM images of dislocation substructure with (a) uniform dislocation density and

(b) a cluster in the $\mathrm{C}-\mathrm{Nb}-\mathrm{V}$ as-rolled steel

\section{Mechanical properties}

Mechanical properties of both steels were studied in the as-rolled and annealed conditions, during forward and reverse loading (Figure 5). The $\mathrm{C}-\mathrm{Nb}-\mathrm{V}$ steel showed higher compression yield stress than the $\mathrm{C}-\mathrm{Nb}$ steel due to the larger dislocation density and precipitate number density (Table 7). However, $2.7 \%$ increase in the yield stress from the $\mathrm{C}-\mathrm{Nb}$ as-rolled to the $\mathrm{C}-\mathrm{Nb}-\mathrm{V}$ as-rolled steel appears to be inconsistent with the large increase in particle number density and increase in dislocation density. This may be due to the small coherent particles, $(\mathrm{Cu}, \mathrm{V})$-rich with a diameter below $50 \mathrm{~nm}$, not pinning the dislocations strongly enough to increase the yield stress. The strength difference is consistent with the hardness difference, Table 3. Annealing did not affect the compression yield stress significantly. In the $\mathrm{C}-\mathrm{Nb}$ steel, where particle number density is relatively low and dislocation-dislocation interaction is the main source of work-hardening. Whilst annealing decreased the dislocation density, the finish rolling temperature of $745{ }^{\circ} \mathrm{C}$ resulted in a relatively low dislocation density in the as-rolled steel, meaning that the yield strength is more dependent on grain size, which did not change in annealing. In the $\mathrm{C}-\mathrm{Nb}-\mathrm{V}$ steel, where dislocationparticle interaction is a more significant contributor to strength; dislocation density and particle number density decrease during annealing would be expected to result in a yield stress decrease. However, as average particle diameter increased, the number of particles effectively pinning the dislocations may also increase, and hence a yield stress decrease is not observed; this is discussed further below.

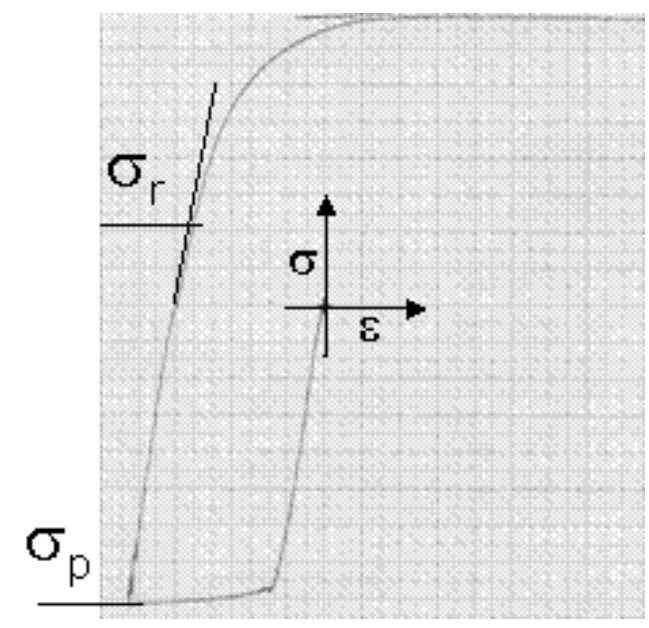

Figure 5 Typical stress-strain curve during compression-tension testing

Table 7 The microstructure - yield stress correlation for the plates mid-thickness position

\begin{tabular}{|c|c|c|c|c|c|c|}
\hline \multirow[b]{3}{*}{$\begin{array}{l}\text { Steel } \\
\text { grade }\end{array}$} & \multicolumn{5}{|c|}{ Parameters of microstructure } & \multirow{3}{*}{ 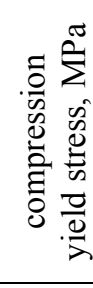 } \\
\hline & \multirow[b]{2}{*}{ 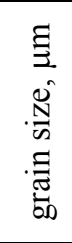 } & \multirow[b]{2}{*}{ 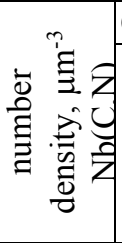 } & \multicolumn{2}{|c|}{$\mathrm{CuS}+\mathrm{V}(\mathrm{CN})$} & \multirow[b]{2}{*}{ 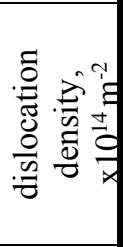 } & \\
\hline & & & 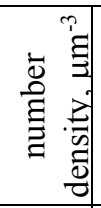 & 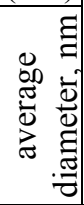 & & \\
\hline $\begin{array}{l}\mathrm{C}-\mathrm{Nb} \\
\text { annealed }\end{array}$ & 3.0 & 0.42 & - & - & 1.1 & 484 \\
\hline $\begin{array}{l}\mathrm{C}-\mathrm{Nb} \\
\text { as-rolled }\end{array}$ & 3.0 & 0.42 & - & - & 2.3 & 485 \\
\hline $\begin{array}{l}\mathrm{C}-\mathrm{Nb}-\mathrm{V} \\
\text { annealed }\end{array}$ & 2.9 & 2.56 & 1426 & 16.3 & 1.5 & 497 \\
\hline $\begin{array}{l}\mathrm{C}-\mathrm{Nb}-\mathrm{V} \\
\text { as-rolled }\end{array}$ & 2.9 & 2.56 & 3873 & 6.3 & 4.0 & 498 \\
\hline
\end{tabular}


Mechanical properties in the reverse direction were assessed with the Bauschinger stress parameter [23] (Figure 5,6):

$$
\beta_{\sigma}=\frac{\sigma_{\mathrm{p}}-\sigma_{\mathrm{r}}}{\sigma_{\mathrm{p}}}
$$

where $\sigma_{\mathrm{p}}$ - maximum pre-stress and $\sigma_{\mathrm{r}}-$ the yield stress in the reverse direction taken at the point where the stress-strain curve deviates from the elastic deformation straight line (approximately $0.1 \%$ strain).

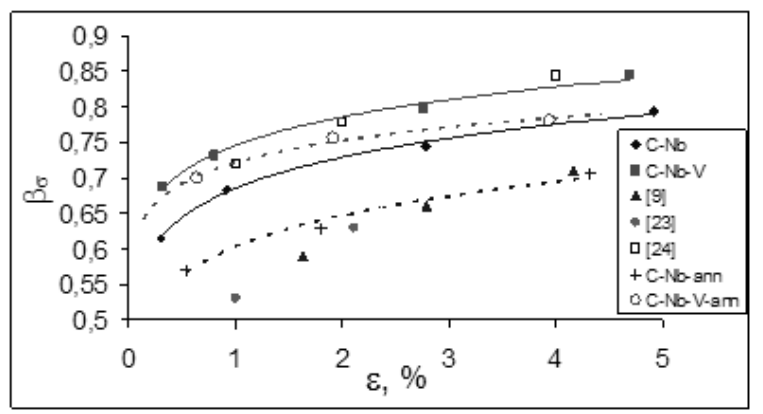

Figure 6 The Bauschinger stress parameter

Table 8The particle-dislocation-Bauschinger effect correlation

\begin{tabular}{|c|c|c|c|c|c|c|}
\hline \multirow[b]{3}{*}{$\begin{array}{l}\text { Steel } \\
\text { grade }\end{array}$} & \multirow{2}{*}{\multicolumn{2}{|c|}{$\frac{\mathrm{CuS}+\mathrm{V}(\mathrm{CN})}{3-50 \mathrm{~nm}}$}} & \multirow{3}{*}{ 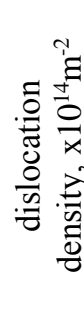 } & \multirow{3}{*}{ 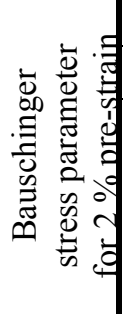 } & \multirow{2}{*}{\multicolumn{2}{|c|}{$\frac{\mathrm{CuS}+\mathrm{V}(\mathrm{CN})}{12-50 \mathrm{~nm}}$}} \\
\hline & & & & & & \\
\hline & 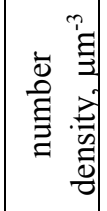 & 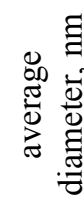 & & & 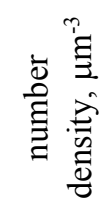 & 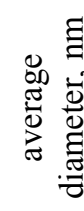 \\
\hline \begin{tabular}{|l|}
$\mathrm{C}-\mathrm{Nb}$ \\
annealed
\end{tabular} & - & - & 1.1 & 0.637 & - & - \\
\hline \begin{tabular}{|l|}
$\mathrm{C}-\mathrm{Nb}$ \\
as-rolled
\end{tabular} & - & - & 2.3 & 0.725 & - & - \\
\hline $\begin{array}{l}\mathrm{C}-\mathrm{Nb}-\mathrm{V} \\
\text { annealed }\end{array}$ & 1426 & 16.3 & 1.5 & 0.750 & 900 & 19.0 \\
\hline \begin{tabular}{|l|}
$\mathrm{C}-\mathrm{Nb}-\mathrm{V}$ \\
as-rolled
\end{tabular} & 3873 & 6.3 & 4.0 & 0.775 & 190 & 19.3 \\
\hline
\end{tabular}

With the increase in pre-strain (dislocation density increase) and microalloying element content (particle number density increase) the Bauschinger stress parameter increases (Figure 6). Annealing led to the stress parameter decreasing due to the dislocation density decrease. Hence, with increases in dislocation density and particle number density, the yield stress drop during reverse deformation increases. Qualitatively, this corresponds to the back stress and Orowan theories of the Bauschinger effect $[13,14]$; according to which an increase in the number density of dislocation-obstacle interaction sites results in the back stress increasing leading to the yield stress drop in the reverse direction increasing. However, the quantitative increase in the Bauschinger stress parameter of $3.2 \%$ from the $\mathrm{C}-\mathrm{Nb}-\mathrm{V}$ annealed to the $\mathrm{C}-\mathrm{Nb}-\mathrm{V}$ as-rolled (where dislocation density is the only difference) and $6.5 \%$ from the $\mathrm{C}-\mathrm{Nb}$ as-rolled to the $\mathrm{C}-\mathrm{Nb}-\mathrm{V}$ as-rolled steel (where dislocation density and number density of small $(\mathrm{CuS}+\mathrm{V}(\mathrm{CN}))$ particles is different) is less than might be expected, especially considering the change in particle number density in the range 3-50nm (Table 8). However, not all the particles equally contribute to strength. It is known, that the particle pinning mechanism depends on the particle diameter and type (Figure 7). Small coherent particles can be cut by moving dislocations, which will happen more easily for lower particle strength (due to different chemistries).
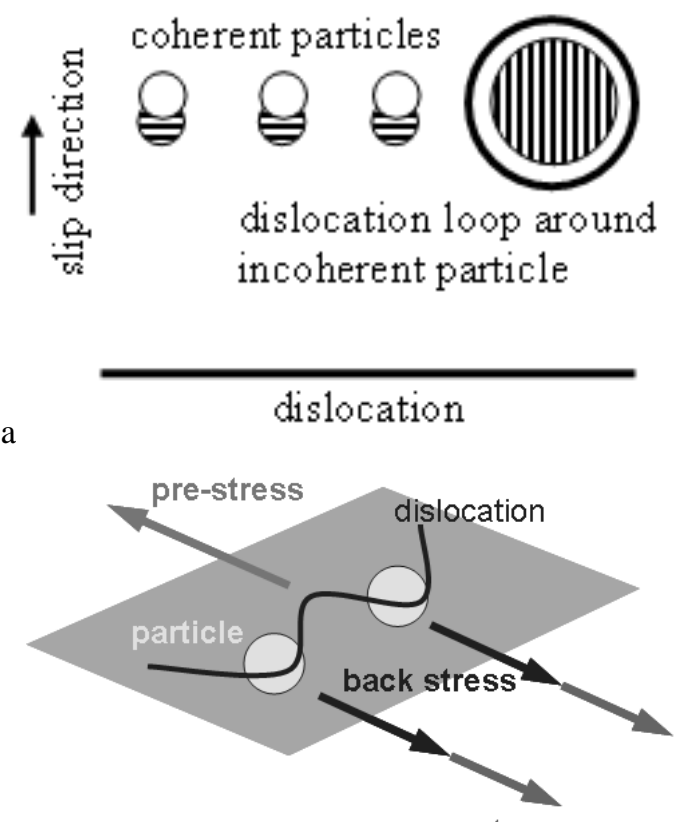

b

reverse stress

Figure 7 Schematic diagram of dislocationparticle interaction during (a) forward and (b) reverse loading

Dislocation-particle interaction investigation has shown, that the $\mathrm{Cu}-\mathrm{V}$-rich particles in the $\mathrm{C}-\mathrm{Nb}-\mathrm{V}$ steel are not effective in dislocation pinning if the particle diameter is less than about $12 \mathrm{~nm}$ (Figure 8). Thus, considering only particles in the $12-50 \mathrm{~nm}$ diameter range, it can be seen that annealing led to an effective particle number density increase from 190 
$\mu \mathrm{m}-3$ in the $\mathrm{C}-\mathrm{Nb}-\mathrm{V}$ as-rolled steel to $900 \mu \mathrm{m}-3$ in the $\mathrm{C}-\mathrm{Nb}-\mathrm{V}$ annealed steel (Table 8). As a result, the Bauschinger stress parameter decrease due to the dislocation density decrease was not significant, as it was compensated by the increase in the effective particle number density.

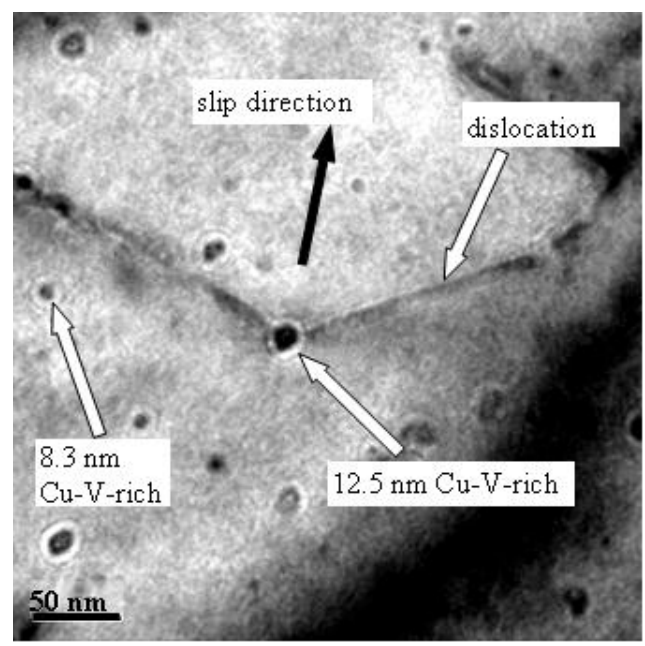

Figure 8 A dislocation-particle interaction site in the $\mathrm{C}-\mathrm{Nb}-\mathrm{V}$ steel

Thus, when predicting the strength and Bauschinger parameters, not only the particle volume fraction and number density, but also particle chemistry, size, and distribution in the matrix, should be taken into account. In the present work, the effective particle diameter was found for the $\mathrm{Cu}$-rich particles. However, particle chemistry will probably influence the magnitude of the effective particle diameter via interatomic bond strength and particle lattice type. Therefore, further work is required to fully understand the particle-dislocation interaction and to quantify its influence on the mechanical properties development.

\section{CONCLUSIONS}

Two pipeline steel plates, $\mathrm{C}-\mathrm{Nb}(\mathrm{X} 60)$ and $\mathrm{C}-$ $\mathrm{Nb}-\mathrm{V}$ (X65), have been characterized in terms of grain size, precipitates, and dislocation density, in the as-rolled and annealed conditions. Compressiontension reverse strain tests were carried out to determine the Bauschinger stress parameter, which has been related to the dislocation and precipitate characteristics. The main results are as follows:

1. During the reverse deformation the Bauschinger stress parameter increases with an increase in the particle number density and dislocation density. Quantitative contribution of particles and dislocations on the Bauschinger effect depends on the particle chemistry, size, and distribution in the matrix.

2. The $\mathrm{Cu}-\mathrm{V}$-rich particles were found to be ineffective in dislocation pinning during slip if the particle diameter is less than $12 \mathrm{~nm}$.

\section{ACKNOWLEDGMENTS}

The authors would like to thank Corus U.K. Ltd. For provision of test material. Thanks are due to the Department of Metallurgy and Materials for the provision of research facilities at the University of Birmingham. One of the authors, (A.K.) is grateful to 'The Universities, U.K.' for awarding the scholarship to carry out his research in the U.K.

\section{REFERENCES}

1. R.C. Ratnapuli and E.C. Rodrigues, Metals Technology, Vol.9, Nov., 1982, p. 440 - 445.

2. M. Graf and H.G. Hillenbrand, Production of large diameter line pipe - state of the art and future development trends, EUROPIPE, GmbH, www.europipe.de.

3. H.G. Hillenbrand, M. Graf and C. Kalwa, Development and production of high strength pipeline steels, EUROPIPE, GmbH, www.europipe.de, 2001.

4. H.G. Hillenbrand, C. Kalwa and A. Liessem, Technological solutions for ultra-high strength gas pipelines, EUROPIPE, GmbH, www.europipe.de, 2005 .

5. H.G. Hillenbrand, A. Liessem, K. Biermann, C.J. Heckmann and V. Schwinn, Development of high strength material and pipe production technology for grade X120 line pipe, EUROPIPE, GmbH, www.europipe.de, 2004.

6. A. Streisselberger, J. Bauer, P. Fluss, H.G. Hillenbrand and P. Cordon, High strength steel 
plates for line pipes in grades up to X100, EUROPIPE, GmbH, www.europipe.de.

7. B. Hwang, S. Lee, Y.M. Kim, N.J. Kim and J.Y. Yoo, Metallurgical and Materials Transactions A, Vol. 36, July, 2005, p. 1793-1805.

8. J. Bauer, P. Fluss, E. Amoris and V. Schwinn, Ironmaking and Steelmaking, Vol. 32, №4, 2005, p. $325-330$.

9. T.C. Harrison, R.T. Weiner and G.D. Fearnehough, Journal of Iron and Steel Institute, May, 1972, p. 334-336.

10. K. Nakajima, W. Mizutani, T. Kikuma and H. Matumoto, Transactions ISIJ, Vol. 15, 1975, p.1-10.

11. J.P. Ormandy, M. Strangwood and C.L. Davis, Material Science and Technology, Vol. 19, May, 2003, p. $595-601$.

12. K. Han, C.J. Van Tyne and B.S. Levy, Metallurgical and Materials Transactions, Vol. 36A, Sept., 2005, p. $2379-2384$.

13. P.S. Bate and D.V. Wilson, Acta Metallurgica, Vol. 34, № 6, 1986, p. 1097 - 1105.

14. L.M. Brown, Scripta Metallurgica, Vol. 11, 1977, p. $127-131$.

15. A.G. Kostryzhev, M. Strangwood and C.L. Davis, Materials Technology: Advanced Performance Materials, Vol.22, № 3, 2007, p. 166-172.

16. D. Williams and C.B. Carter, Transmission electron microscopy, II - Diffraction, New York, Plenum Press, 1996.

17. C.L. Davis and M. Strangwood, Journal of Material Science, Vol. 37, 2002, p. 1083-1090.

18. T. Gladman, The physical metallurgy of microalloyed steels, the Institute of Materials, Cambridge University Press, 1997.

19. I. Madariaga, J.L. Romero and I. Gutierrez, Metallurgical and Materials Transactions, Vol. 29A, March., 1998, p. 1003 - 1015.

20. B. Garbarz, J. Marcisz and J. Wojtas, Material Chemistry and Physics, Vol. 81, 2003, p. 486 - 489.

21. F. Yin, T. Hanamura, O. Umezawa and K. Nagai, Material Science and Engineering A, Vol. 354, 2003, p. $31-39$.
22. C.F. Robertson, K. Obrtlik and B. Marini, Journal of Nuclear Materials, Vol. 366, 2007, p. $58-69$.

23. A. Abel and H. Muir, Philosophical Magazine, Vol. 26, 1972, p. 489 - 504.

24. D.N. Williams, Metallurgical Transactions A, Vol. 11, Sept., 1980, p. 1629 - 1631. 